\title{
A Novel FCC Catalyst Based on a Porous Composite Material Synthesized via an In Situ Technique
}

DOI: $10.15255 / K U I .2015 .035$

KUI-35/2015

Original scientific paper

Received June 29, 2015 Accepted July 28, 2015

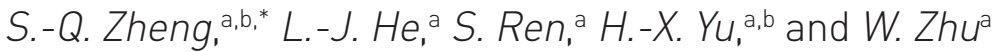 \\ a Department of Chemistry and Chemical Engineering, Hunan Institute of \\ Science and Technology, Yueyang 414006 , Hunan, P.R. China \\ b Hunan Province Key Laboratory of Specialty Petrochemicals Catalysis and \\ Separation, Yueyang 414 000, Hunan, P.R. China
}

\begin{abstract}
\| Abstract
To overcome diffusion limitations and improve transport in microporous zeolite, the materials with a wide-pore structure have been developed. In this paper, composite microspheres with hierarchical porous structure were synthesized by an in situ technique using sepiolite, kaolin and pseudoboehmite as raw material. A novel fluid catalytic cracking (FCC) catalyst for maximizing light oil yield was prepared based on the composite materials. The catalyst was characterized by XRD, FT-IR, SEM, nitrogen adsorption-desorption techniques and tested in a bench FCC unit. The results indicated that the catalyst had more meso- and macropores and more acid sites than the reference catalyst, and thus can increase light oil yield by $1.31 \%$, while exhibiting better gasoline and coke selectivity.
\end{abstract}

\section{\| Keywords}

FCC catalyst, hierarchical porous structure, in situ synthesis, catalytic properties

\section{Introduction}

Microporous zeolite $\mathrm{Y}$, which is the main active component in Fluid Catalytic Cracking (FCC) catalysts, plays an important role in the modern petrochemical industry. The narrow pores of microporous zeolite limit its application for the conversion of bulky molecules. The microporous structure typically results in relatively longer diffusion paths. Due to diffusion limitations on chemical reactions and mass transfer, many approaches for overcoming this challenge and improving transport in microporous zeolite have been developed. ${ }^{1-3}$

Zeolite $\mathrm{Y}$ can be prepared using a conventional gel synthesis method or in situ crystallization. In the latter synthesis technique, the active components are crystallized into the matrices, which enhances the thermostability of the FCC catalyst compared to the former. ${ }^{4-6}$ Kaolin is usually used for the preparation of such catalyst. Since kaolin is, in essence, the pure mineral kaolinite, it is composed of aluminum and silicon oxides, i.e. $2 \mathrm{SiO}_{2} \cdot \mathrm{Al}_{2} \mathrm{O}_{3} \cdot 2 \mathrm{H}_{2} \mathrm{O}$, as with a zeolite.

Sepiolite is a hydrated magnesium silicate with the theoretical molecular formula $\mathrm{Mg}_{8} \mathrm{Si}_{12} \mathrm{O}_{30}(\mathrm{OH})_{4}\left(\mathrm{H}_{2} \mathrm{O}\right)_{4} \cdot 8 \mathrm{H}_{2} \mathrm{O}$. Sepiolite presents a high specific surface and special structural characteristics based on the folding of the crystal structure when the zeolitic water has been removed by thermal treatment. The potential to use sepiolite and its derivatives for applications as a catalyst or catalyst carrier is great. ${ }^{7-9}$

\footnotetext{
* Corresponding author: Dr. Shu-Qin Zheng

e-mail: zhengshuqin37@163.com
}

In this study, to overcome the challenges of using microporous zeolite, a new synthesis technology for the production of a hierarchical zeolite material with controllable hierarchical mesopore using in situ crystallization has been developed. The aim of the current work was to study the synthesis and properties of composite materials that have a wide-pore structure and were obtained using sepiolite, kaolin and pseudoboehmite, and to investigate the catalytic properties of the FCC catalyst prepared from the composite material.

\section{Experimental}

\subsection{Materials}

Sepiolite was obtained from China Liuyang Sepiolite Mining Co., Ltd., kaolin was obtained from China Kaolin Co., Ltd., and pseudoboehmite was obtained from China Aluminum Co., Ltd. (The composition of compounds and mixtures is expressed in terms of the mass fraction.)

Sodium silicate (containing $22.8 \% \mathrm{SiO}_{2}, 6.9 \% \mathrm{Na}_{2} \mathrm{O}$ ) and sodium metaaluminate (containing $20.8 \% \mathrm{Na}_{2} \mathrm{O}$, $3.0 \% \mathrm{Al}_{2} \mathrm{O}_{3}$ ) were purchased from the Yueyang Jucheng Chemical Co., Ltd.

\subsection{Synthesis of composite materials}

The typical synthesis of composite materials involved the following steps:

Approximately $4 \%$ of dispersant (sodium silicate) and $2 \%$ of a pore-enlarging additive (ammonium bicarbonate) 
were blended with kaolin to form an aqueous slurry with a $35 \%$ solid content, and precursor microspheres A (PMA) of particle size 0-150 $\mu \mathrm{m}$, were produced by spray drying. The PMA were calcined at $960{ }^{\circ} \mathrm{C}$ for $2 \mathrm{~h}$ to produce type A microspheres (CMA).

Sepiolite and pseudoboehmite were blended in mass ratio $4: 1$ to form an aqueous slurry with a $35 \%$ solid content. After the addition of a certain amount of a hydrochloric acid solution at room temperature, followed by stirring $2 \mathrm{~h}$, washing, and filtering, the precursor microspheres $B$ (PMB) of particle size $0-150 \mu \mathrm{m}$ were produced by spray drying. The PMB were calcined at $750-800{ }^{\circ} \mathrm{C}$ for $2 \mathrm{~h}$ to produce type $B$ microspheres $(\mathrm{CMB})$.

A mixture of sodium silicate, sodium hydroxide, distilled water, zeolite initiator (i.e., the initiator was an amorphous gel that accelerated the formation of the $\mathrm{NaY}$ zeolite prepared with a composition of $16 \mathrm{Na}_{2} \mathrm{O} \cdot \mathrm{Al}_{2} \mathrm{O}_{3} \cdot 15 \mathrm{SiO}_{2} \cdot 320 \mathrm{H}_{2} \mathrm{O}$ ), CMA and $\mathrm{CMB}(\mathrm{CMA}: \mathrm{CMB}=1: 1)$ was mixed in a reactor and heated to $95-100{ }^{\circ} \mathrm{C}$ for $24-30 \mathrm{~h}$ to synthesize the composite material (SCM) containing $\mathrm{Y}$ zeolite as microspheres. The synthesis of SCM involves an inorganic reaction with a stoichiometry of $\mathrm{Na}_{2} \mathrm{O}: \mathrm{SiO}_{2}: \mathrm{Al}_{2} \mathrm{O}_{3}: \mathrm{H}_{2} \mathrm{O}=6.1: 12: 1: 300$.

After crystallization, the solid product was filtered and washed with distilled water followed by drying to afford SCM.

\subsection{Catalyst preparation}

The catalyst (CAT) was prepared from the as-synthesized SCM. First, SCM was exchanged one or more times with approximately 10 to $30 \%$ of ammonium chloride to replace the sodium. Then, the microspheres were exchanged with $3 \%$ of lanthanum chloride, followed by calcination at $500-600{ }^{\circ} \mathrm{C}$ with $100 \%$ steam for $2 \mathrm{~h}$ to generate the active sites and appropriate pore structures necessary for catalytic cracking.

\subsection{Characterization}

The $\mathrm{SiO}_{2}$ content was gravimetrically determined, and the $\mathrm{Na}_{2} \mathrm{O}$ and $\mathrm{K}_{2} \mathrm{O}$ contents were determined using flame photometry. In addition, $\mathrm{Al}_{2} \mathrm{O}_{3}$ as well as $\mathrm{Fe}_{2} \mathrm{O}_{3}$ and $\mathrm{RE}_{2} \mathrm{O}_{3}$ were determined using complexometric and spectrophotometric methods, respectively.

X-ray diffraction: Relative crystallinity, silica/alumina, crystalline unit cell size and phase of samples were recorded on a Rigaku Ultima IV diffractometer using $\mathrm{Cu}-\mathrm{K} \alpha$ radiation $(\lambda=1.54056 \AA)$ at an operation voltage and current of $40 \mathrm{kV}$ and $30 \mathrm{~mA}$, respectively. The samples were scanned at $0.2^{\circ} \mathrm{min}^{-1}$. The relative crystallinity of $\mathrm{Y}$ zeolite was estimated according to the equation

$$
\begin{array}{r}
\text { relative crystallinity = peak height of product/ } \\
\text { peak height of reference, }
\end{array}
$$

based on $2 \theta$ range $22.0-24.5^{\circ}$.
IR spectroscopy (FT-IR): The IR spectra were recorded on an AVATAR 370 FT-IR spectrometer using $\mathrm{KBr}$ as compressed slices, in a range from 400 to $2000 \mathrm{~cm}^{-1}$.

SEM: The morphology and size of the samples were determined using scanning electron microscopy (SEM) (JEOL JSM-6360) after coating with an Au evaporated film.

Nitrogen adsorption-desorption methods: The specific surface areas, pore volumes, and pore size distributions were measured on an ASAP 2020 sorptometer using adsorption and desorption isotherm plots at $77 \mathrm{~K}$. Prior to the measurement, the samples were degassed at $623 \mathrm{~K}$ for $12 \mathrm{~h}$. The surface areas were calculated using the Brunauer-Emmett-Teller (BET) method. The micropore volumes and external surfaces areas were calculated using the t-plot method. The pore parameters, mesopore surface and mesopore volume were calculated from the desorption branches of these isotherms using the $\mathrm{BJH}$ method.

Particle size distribution: A Malvern Micro-P particle size distribution analyser was used for determining the size distribution in the samples.

Attrition index: The attrition index of the catalyst was determined using attrition index analyser by air injection method.

\subsection{Microactivity tests (MAT)}

The activity of the catalyst was investigating using a microactivity test unit. The MAT conditions were as follows: reactor temperature of $460{ }^{\circ} \mathrm{C}$, reaction time of $70 \mathrm{~s}$, weight hourly space velocity (WHSV) of $15 \mathrm{~h}^{-1}$ and catalyst-to-oil mass ratio of 3.2. Prior to the MAT test, the fresh catalyst was steam-deactivated at $800{ }^{\circ} \mathrm{C}$ for $4 \mathrm{~h}$ or $17 \mathrm{~h}$ with $100 \%$ steam.

\subsection{Metal contamination}

The catalysts were contaminated using the Mitchell method. ${ }^{10} \mathrm{~A}$ certain amount of $\mathrm{NH}_{4} \mathrm{VO}_{3}$ and $\mathrm{Ni}\left(\mathrm{NO}_{3}\right)_{2}$ was dissolved in distilled water, and the obtained solution was mixed with the catalyst using the incipient wetness impregnation technique. The mixture was dried in an oven at $120^{\circ} \mathrm{C}$ for $8 \mathrm{~h}$ and then calcined at $540{ }^{\circ} \mathrm{C}$ for $2 \mathrm{~h}$.

\subsection{Catalytic cracking tests}

We chose a comparable commercial resid catalyst as the base reference FCC catalyst (RCAT). It was obtained from a domestic refinery that is based on REUSY zeolite with a surface area of $283.49 \mathrm{~m}^{2} \mathrm{~g}^{-1}$ and a pore volume of $0.22 \mathrm{~cm}^{3} \mathrm{~g}^{-1}$. The performance of the CAT and RCAT was tested in a small-scale fixed fluid bed reactor. The test conditions were as follows: reactor temperature of $520^{\circ} \mathrm{C}$, WHSV of $19 \mathrm{~h}^{-1}$ and catalyst-to-oil mass ratio of 6 . In each run, $30 \mathrm{~g}$ of feedstock oil was used, and the feed injection time was $33 \mathrm{~s}$. Prior to the test in fixed fluid bed reactor, the catalyst was steam-deactivated at $800{ }^{\circ} \mathrm{C}$ for $17 \mathrm{~h}$ with 
$100 \%$ steam. The feedstock oil consisted of a mixture of $70 \%$ vacuum gas oil (VGO) and $30 \%$ vacuum tower bottom (VTB) and its properties are listed in Table 1.

Table 1 - Properties of the feedstock oil

Tablica 1 - Svojstva sirovine za FCC

\begin{tabular}{|c|c|}
\hline $\begin{array}{l}\text { Variable } \\
\text { Veličina }\end{array}$ & $\begin{array}{l}\text { Value } \\
\text { Vrijednost }\end{array}$ \\
\hline $\begin{array}{l}\text { density }\left(20^{\circ} \mathrm{C}\right) / \mathrm{g} \mathrm{cm}^{-3} \\
\text { gustoća }\left(20^{\circ} \mathrm{C}\right) / \mathrm{g} \mathrm{cm}^{-3}\end{array}$ & 0.9222 \\
\hline $\begin{array}{l}\text { viscosity }\left(50^{\circ} \mathrm{C}\right) / \mathrm{mm}^{2} \mathrm{~s}^{-1} \\
\text { viskoznost }\left(50^{\circ} \mathrm{C}\right) / \mathrm{mm}^{2} \mathrm{~s}^{-1}\end{array}$ & 79.48 \\
\hline $\begin{array}{l}\text { Conradson carbon residue /\% } \\
\text { Conradsonov koksni ostatak/\% }\end{array}$ & 3.8 \\
\hline $\begin{array}{l}\text { elemental composition } \\
\text { elementni sastav }\end{array}$ & $w / \%$ \\
\hline C & 85.59 \\
\hline $\mathrm{H}$ & 11.43 \\
\hline $\mathrm{N}$ & 0.44 \\
\hline S & 1.93 \\
\hline $\begin{array}{l}\text { metals } \\
\text { metali }\end{array}$ & $w / \mu g g^{-1}$ \\
\hline $\mathrm{Cu}$ & 0.058 \\
\hline $\mathrm{Fe}$ & 6.66 \\
\hline $\mathrm{Ni}$ & 5.68 \\
\hline V & 8.08 \\
\hline $\begin{array}{l}\text { SARA analysis } \\
\text { analiza SARA }\end{array}$ & $w / \%$ \\
\hline $\begin{array}{l}\text { saturate } \\
\text { zasićeni }\end{array}$ & 56.49 \\
\hline $\begin{array}{l}\text { aromatics } \\
\text { aromati }\end{array}$ & 30.01 \\
\hline $\begin{array}{l}\text { resin } \\
\text { smole }\end{array}$ & 11.58 \\
\hline $\begin{array}{l}\text { asphaltene } \\
\text { asfalteni }\end{array}$ & 1.92 \\
\hline $\begin{array}{l}\text { distillation fraction } \\
\text { destilacijska frakcija }\end{array}$ & $\begin{array}{l}\text { temperature } /{ }^{\circ} \mathrm{C} \\
\text { temperatura } /{ }^{\circ} \mathrm{C}\end{array}$ \\
\hline $\begin{array}{l}\text { initial point } \\
\text { početna točka }\end{array}$ & 286 \\
\hline $10 \%$ & 350 \\
\hline $30 \%$ & 401 \\
\hline $50 \%$ & 455 \\
\hline $70 \%$ & 500 \\
\hline $90 \%$ & 556 \\
\hline $\begin{array}{l}\text { dry point } \\
\text { točka isušivanja }\end{array}$ & $>556$ \\
\hline
\end{tabular}

\section{Results and discussion}

\subsection{Properties of SCM and CAT}

In the in situ synthesis method, both the $\mathrm{Al}-\mathrm{O}$ and $\mathrm{Si}-\mathrm{O}$ species to form zeolite come from the kaolin mi- crospheres. ${ }^{11}$ In the current study, the $\mathrm{Al}-\mathrm{O}$ and $\mathrm{Si}-\mathrm{O}$ species were leached from CMA and $\mathrm{CMB}$ microspheres under caustic conditions and thus resulted in the formation of more meso- and macropores in calcined microspheres. The properties of SCM are listed in Table 2. The SCM microspheres containing zeolite $\mathrm{Y}$ in its sodium form had a relative crystallinity higher than $55 \%$ with a silica/alumina amount ratio of 5.4. The composite microspheres exhibited a much larger external surface area, total pore volume, $\mathrm{BJH}$ pore volume, and average pore diameter.

Table 2 - Properties of SCM and CAT

Tablica 2 - Svojstva SCM-a i CAT-a

\begin{tabular}{|c|c|c|c|c|}
\hline & SCM & $\mathrm{NaY}$ & CAT & RCAT \\
\hline $\begin{array}{l}\text { composition } \\
\text { sastav }\end{array}$ & \multicolumn{4}{|c|}{$w / \%$} \\
\hline $\mathrm{Na}_{2} \mathrm{O}$ & 9.52 & 8.19 & 0.19 & 0.16 \\
\hline $\mathrm{Al}_{2} \mathrm{O}_{3}$ & 37.89 & 23.76 & 36.21 & 50.23 \\
\hline $\mathrm{Fe}_{2} \mathrm{O}_{3}$ & 0.35 & 0.22 & 0.33 & 0.31 \\
\hline $\mathrm{La}_{2} \mathrm{O}_{3}$ & - & - & 3.8 & 3.9 \\
\hline $\begin{array}{l}\text { BET surface area } / \mathrm{m}^{2} \mathrm{~g}^{-1} \\
\text { ploština po BET-u } / \mathrm{m}^{2} \mathrm{~g}^{-1}\end{array}$ & 542.77 & 721.58 & 433.18 & 283.49 \\
\hline $\begin{array}{l}\text { BJH surface area } / \mathrm{m}^{2} \mathrm{~g}^{-1} \\
\text { ploština po BJH-u } / \mathrm{m}^{2} \mathrm{~g}^{-1}\end{array}$ & 129.19 & 46.69 & 131.27 & 135.99 \\
\hline $\begin{array}{l}\text { micropore surface area/ } \\
\mathrm{m}^{2} \mathrm{~g}^{-1} \\
\text { ploština mikropora } / \mathrm{m}^{2} \mathrm{~g}^{-1}\end{array}$ & 356.11 & 689.52 & 311.92 & 189.04 \\
\hline $\begin{array}{l}\text { external surface area / } \\
\mathrm{m}^{2} \mathrm{~g}^{-1} \\
\text { vanjska ploština } / \mathrm{m}^{2} \mathrm{~g}^{-1}\end{array}$ & 186.66 & 32.06 & 121.26 & 94.44 \\
\hline $\begin{array}{l}\text { total pore volume } / \mathrm{cm}^{3} \mathrm{~g}^{-1} \\
\text { ukupni obujam pora/ } \\
\mathrm{cm}^{3} \mathrm{~g}^{-1}\end{array}$ & 0.38 & 0.34 & 0.39 & 0.22 \\
\hline $\begin{array}{l}\text { micropore volume } / \mathrm{cm}^{3} \mathrm{~g}^{-1} \\
\text { obujam mikropora } / \mathrm{cm}^{3} \mathrm{~g}^{-1}\end{array}$ & 0.16 & 0.31 & 0.14 & 0.10 \\
\hline $\begin{array}{l}\mathrm{BJH} \text { pore volume } / \mathrm{cm}^{3} \mathrm{~g}^{-1} \\
\text { obujam pora po } \mathrm{BJH}-\mathrm{u} / \\
\mathrm{cm}^{3} \mathrm{~g}^{-1}\end{array}$ & 0.23 & 0.036 & 0.26 & 0.14 \\
\hline $\begin{array}{l}\text { average pore diameter } / \mathrm{nm} \\
\text { prosječni promjer pora } / \mathrm{nm}\end{array}$ & 6.92 & 2.71 & 7.11 & 4.20 \\
\hline $\begin{array}{l}\text { unit cell size / } \mathrm{nm} \\
\text { veličina jedinične ćelije/nm }\end{array}$ & 24.67 & 24.68 & 24.64 & 24.56 \\
\hline $\begin{array}{l}\text { bulk density } / \mathrm{g} \mathrm{cm}^{-3} \\
\text { gustoća } / \mathrm{g} \mathrm{cm}^{-3}\end{array}$ & 0.66 & - & 0.69 & 0.75 \\
\hline $\begin{array}{l}\text { attrition index } / \% \\
\text { atricijski indeks / \% }\end{array}$ & 1.1 & - & 0.8 & 1.5 \\
\hline $\begin{array}{l}\text { microactivity test } \\
\text { ispit mikroaktivnosti }\end{array}$ & \multicolumn{4}{|c|}{$\begin{array}{l}\text { microactivity } / \% \\
\text { mikroaktivnost } / \%\end{array}$} \\
\hline $4 \mathrm{~h}$ & - & - & 83 & 76 \\
\hline $17 \mathrm{~h}$ & - & - & 71 & 65 \\
\hline $\begin{array}{l}\text { contaminated catalyst } \\
\text { kontaminirani katalizator }\end{array}$ & - & - & 68 & 54 \\
\hline
\end{tabular}


Properties of CAT and RCAT (Table 2) revealed the CAT possessed a larger surface area and pore volume. In comparison to RCAT, CAT had $150 \mathrm{~m}^{2} \mathrm{~g}^{-1}$ more BET surface area and $130 \mathrm{~m}^{2} \mathrm{~g}^{-1}$ more micropore surface area, increased by $52.8 \%$ and $65.0 \%$, respectively. CAT had $0.17 \mathrm{~cm}^{3} \mathrm{~g}^{-1}$ more total pore volume, $0.04 \mathrm{~cm}^{3} \mathrm{~g}^{-1}$ more micropore volume and $0.12 \mathrm{~cm}^{3} \mathrm{~g}^{-1}$ more $\mathrm{BJH}$ pore volume, increased by $77.3 \%, 40.0 \%$ and $85.7 \%$, respectively. CAT had $2.91 \mathrm{~nm}$ bigger average pore diameter, increased by $70.8 \%$. These results indicated that the CAT was richer in meso- and macropores. This phenomenon is also well illustrated in Fig. 4. The results had been confirmed that the residue of the caustic leached kaolin matrix can endow the catalyst with more meso- and macropores, and effectively improve the acidity and stability of the resulting FCC catalyst. CAT exhibited good attrition resistance, leading to less replenishment of fresh catalyst during the FCC process. In comparison to RCAT, MAT at $4 \mathrm{~h}, 17 \mathrm{~h}$ and contaminated condition of CAT increased by $7,6,14 \%$, respectively. The MAT results indicated that CAT had high activity and excellent hydrothermal stability, while levels of contaminant metals were present, the MAT results exhibited excellent vanadium and nickel passivation performance.

\subsection{X-ray diffraction}

The XRD patterns (Fig. 1) revealed that CMA was transformed from kaolin by heat treatment, under treatment temperature, which resulted in an amorphous phase as the major product. However, the characteristic peaks of the Si-Al spinel structure were also observed. The $d_{101}$ value, which is the interplanar distance (i.e., $0.33,0.41 \mathrm{~nm}$,), indicated the existence of a quartz phase. The characteristic XRD peaks of the CMB indicated the existence of a talc phase, which transformed from sepiolite. The XRD patterns of SCM indicated the $\mathrm{Y}$ zeolite structure corresponded to the NaY ASTM standard peaks. ${ }^{12}$

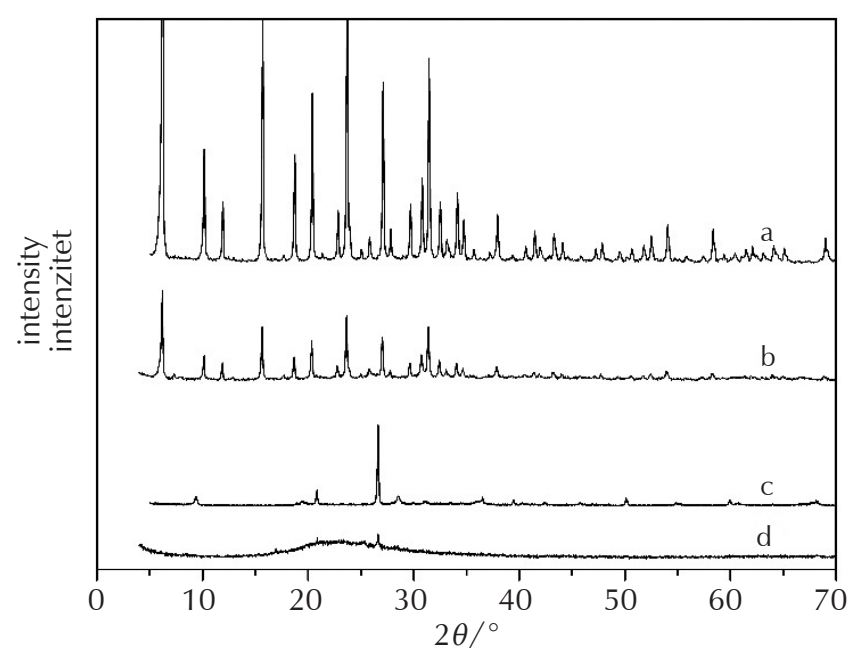

Fig. 1 - XRD patterns of (a) NaY, (b) SCM, (c) CMB, and (d) CMA Slika 1 - Rendgenski difraktogrami: (a) NaY, (b) SCM, (c) CMB, (d) CMA
The XRD patterns (Fig. 2) showed that CAT and RCAT exhibited the crystalline features of zeolite $\mathrm{Y}$. In comparison to the XRD patterns of CAT, RCAT exhibited low intensity peaks due to CAT containing much of the zeolite phase, which is consistent with the XRD relative crystallinity analysis results.

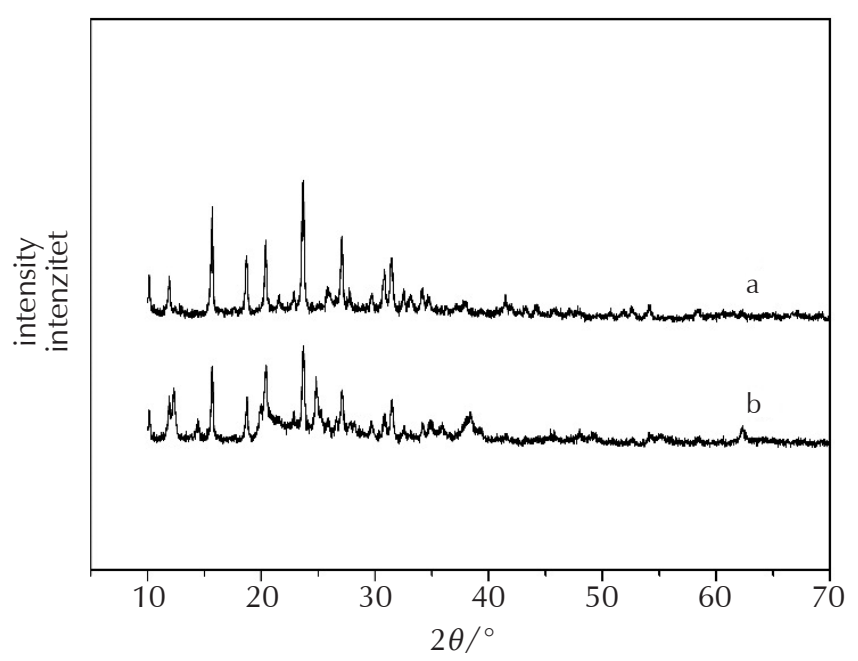

Fig. 2 - XRD patterns of (a) CAT, and (b) RCAT

Slika 2 - Rendgenski difraktogrami: (a) CAT, (b) RCAT

\subsection{FTIR spectroscopy}

IR spectroscopy of adsorbed pyridine is a technique for measuring and distinguishing different types of acid sites on catalyst surfaces. The bands located at 1540 and $1450 \mathrm{~cm}^{-1}$ are used to estimate the amount of pyridine adsorbed on Brönsted and Lewis acid sites, respectively. The acidities determined using FTIR analysis of CAT and RCAT are listed in Table 3. The acid strength distributions are quantitatively calculated from the pyridine adsorbed IR spectra at 200 and $400{ }^{\circ} \mathrm{C}$ (total acid amount and strong acid amount). Based on the results in Table 3, in comparison to RCAT, the strong Brönsted acid and total Brönsted acid amounts were higher for CAT. CAT enhanced the weak Lewis acidity. Strong Lewis acids induce undesirable coke production, but weak Lewis acid sites and higher Brönsted acid sites are needed for cracking selectivity. ${ }^{13-14}$

Table 3 - Acidic properties of CAT (relative strength of absorbance bands)

Tablica 3 - Kiselinska svojstva CAT-a (relativna jakost apsorpcijskih signala)

\begin{tabular}{l|cc|cc}
\hline \multirow{2}{*}{$\begin{array}{l}\text { Samples } \\
\text { Uzorci }\end{array}$} & \multicolumn{2}{c|}{ CAT } & \multicolumn{2}{c}{ RCAT } \\
\cline { 2 - 5 } & Brønsted & Lewis & Brønsted & Lewis \\
\hline $\begin{array}{l}\text { weak acid amount } \\
\text { slabo kisela aktivna mjesta }\end{array}$ & 12.173 & 9.033 & 7.577 & 8.487 \\
$\begin{array}{l}\text { strong acid amount } \\
\text { jako kisela aktivna mjesta }\end{array}$ & 13.205 & 8.758 & 4.476 & 8.171 \\
$\begin{array}{l}\text { total acid amount } \\
\text { ukupna kisela aktivna mjesta }\end{array}$ & 25.378 & 17.79112 .053 & 16.658 \\
\hline
\end{tabular}




\subsection{Scanning electron microscopy}

The SEM micrograph of SCM, Fig. 3(1), showed that the sizes of the $Y$ zeolite particles were $0.4-0.8$ micrometers, which indicated that smaller crystals had agglomerated with the larger particles. The octahedral morphology of the $\mathrm{Y}$ zeolite was observed in all the images. Well-shape bipyramidal FAU crystals are not commonly observed in the reported synthesis from natural clay. ${ }^{15}$ Covarrubias reported that the characteristic bipyramidal-shaped crystals of the FAU zeolite can be obtained from kaolin. ${ }^{16}$

The SEM micrograph of CAT, Fig. 3(2), showed the typical FAU obtained by crystallization, the average particle size was about $0.6 \mu \mathrm{m}$ in diameter.
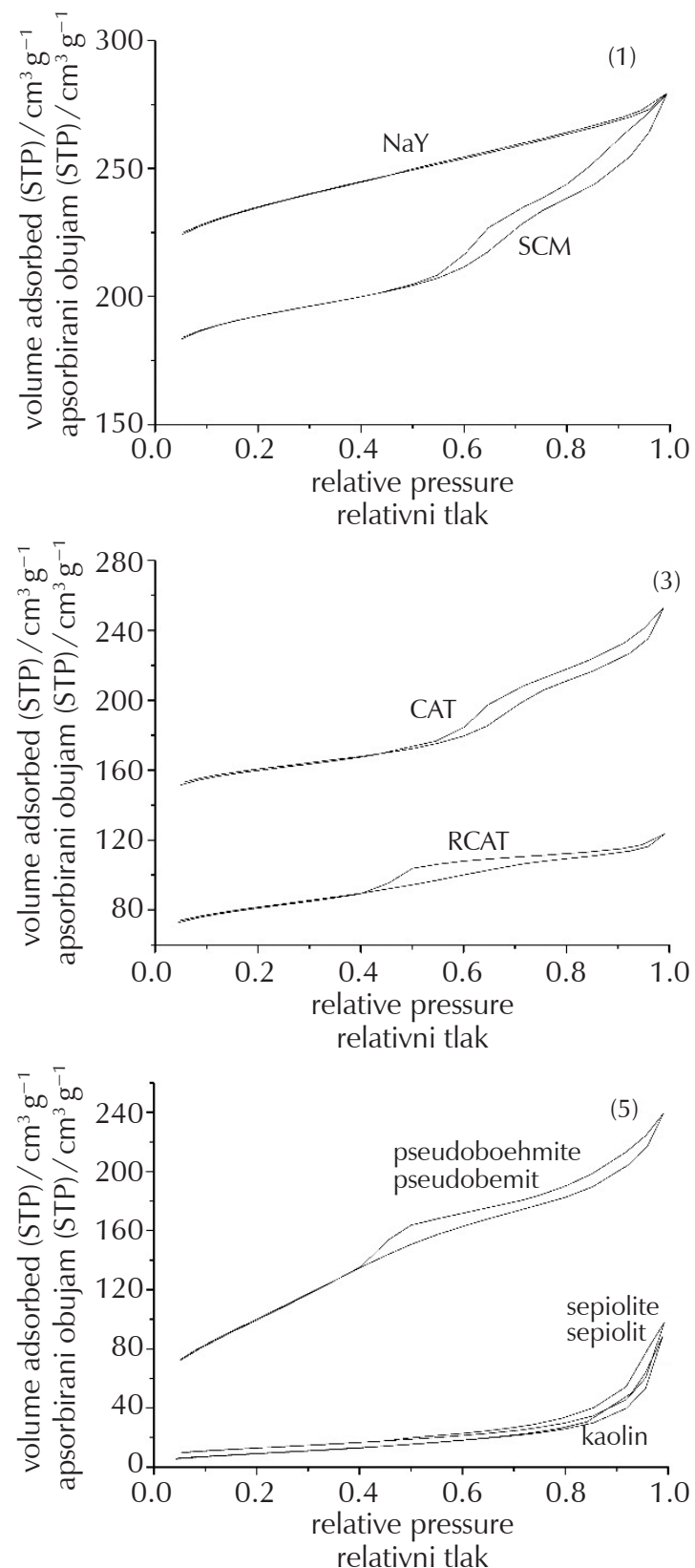
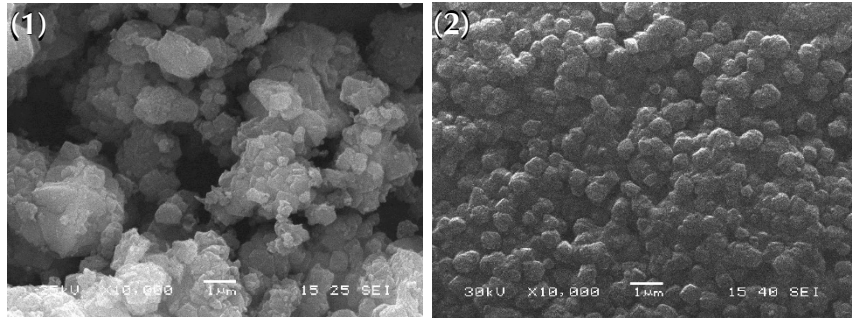

Fig. 3 - SEM images of (1) SCM, and (2) CAT Slika 3 - SEM snimke (1) SCM-a i (2) CAT-a

\subsection{Pore structure}

The nitrogen adsorption-desorption isotherms, the pore size distributions for SCM, CAT, and the raw materials are shown in Fig. 4.
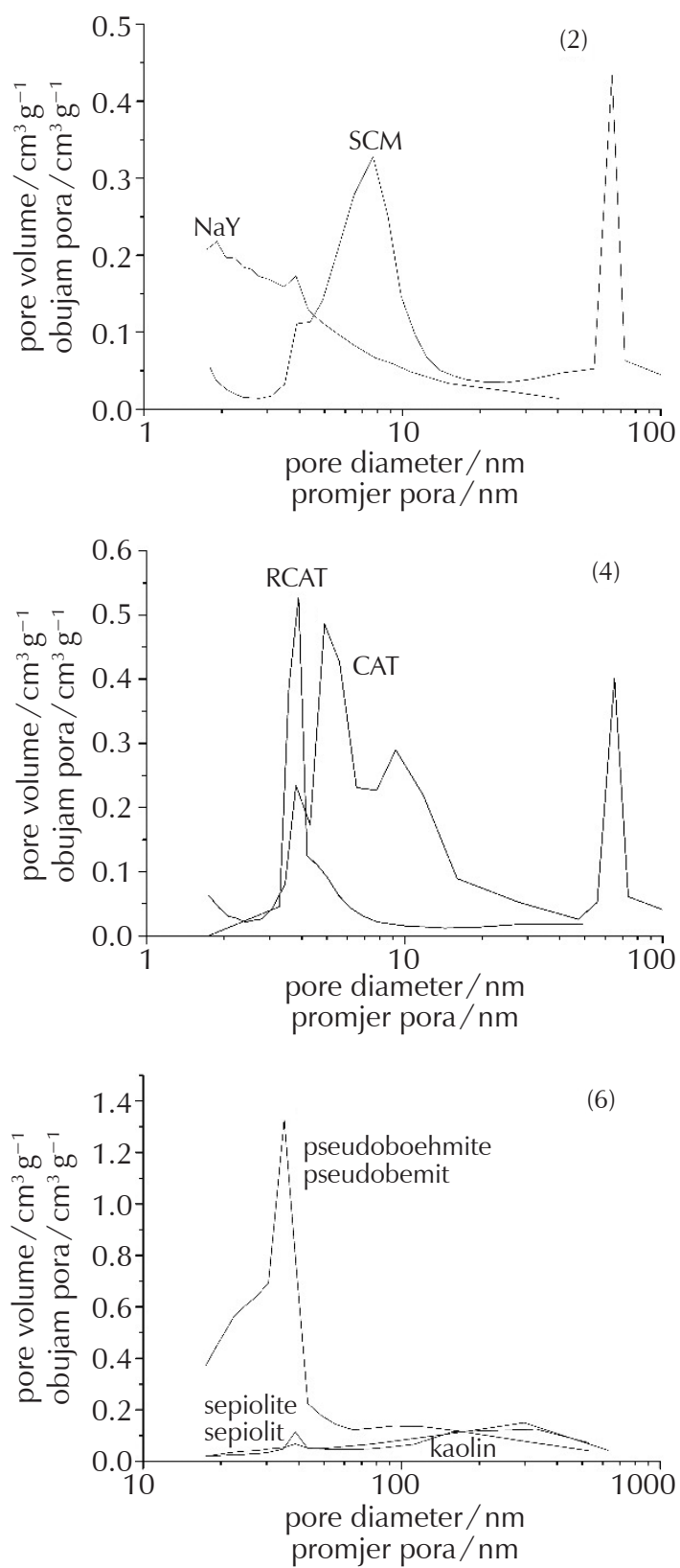

Fig. 4 - Nitrogen adsorption-desorption isotherms and pore size distribution of samples Slika 4 - Apsorpcijsko-desorpcijske izoterme dušika i distribucija promjera pora uzoraka 
As shown in Fig. 4(1), the isotherm for SCM exhibited the representative characteristics of type IV adsorption-desorption. The hysteresis loop that occurred in a relative pressure range $0.50-1.0$ was due to the presence of mesopores and macropores. As shown in Fig. 4(2), the broad distribution of SCM indicated the existence of macropores. SCM possessed a wide pore structure with a trimodal distribution, the distribution was concentrated on approximately $4.0,7.5$, and $65 \mathrm{~nm}$, respectively.

Based on the results in Fig. 4(3), the nitrogen adsorption and desorption branches of the isotherms for CAT exhibited a steeper decrease and a larger hysteresis loop than RCAT, indicating that meso- and macropores existed in CAT. Due to the unique synthesis route, the catalyst was endowed with more meso- and macropores. In addition, in CAT, the NaY zeolite grew in the pores of the calcined microspheres, and therefore, the mass-transfer resistance in the reaction process was effectively reduced. ${ }^{17}$ As shown in Fig. 4(4), CAT possessed a hierarchical porous distribution, the distribution was concentrated on approximately 3.8, 5.0, 9.0, $65 \mathrm{~nm}$, respectively. The distribution of RCAT was observed at approximately $4.0 \mathrm{~nm}$. The unique pore system of CAT should greatly enhance the accessibility of the catalytically active sites inside the microporous channels to larger reactant molecules leading to the accelerated diffusion of products and fewer secondary reactions.

\subsection{Catalytic cracking tests}

In comparison with RCAT, Table 4 shows that CAT had much lower heavy oil, $0.29 \%$ lower LCO yield, 1.60 more gasoline yield, and $0.26 \%$, and $0.22 \%$ lower dry gas and coke yield, respectively. The results indicated that CAT exhibited better heavy oil cracking capability and coke selectivity. The good product selectivity and higher liquid yields of CAT are obviously related to its wide pore structure and its active component. The mesopores and macropores in the catalyst can accelerate the diffusion of the product molecules, and therefore, the secondary reactions leading to dry gas and coke formation were reduced. The micropore channels effectively connect the macropore channels to the macropore channels in CAT, and may decrease unwanted secondary reactions that lead to the formation of dry gas and coke. ${ }^{18}$ By properly increasing the acidity, density, and strength in the pores of zeolite $\mathrm{Y}$, the CAT effectively controlled the ratio of hydrogen transfer activity and crack ability in the catalytic reaction.

The properties of the cracked gasoline are summarized in Table 5. As shown in Table 5, in comparison to RCAT, CAT produced a reduction of $2.51 \%$ in olefin, and the research gasoline and motor gasoline octane numbers increased by $0.7,0.2$ units.

\section{Conclusions}

In this study, new composite microspheres with hierarchical porous structure were synthesized by in situ technique using sepiolite, kaolin and pseudo-boehmite. The as-made composite microspheres containing zeolite $\mathrm{Y}$ in its sodium
Table 4 - Catalytic properties of CAT

Tablica 4 - Katalitičke osobine CAT-a

\begin{tabular}{|c|c|c|}
\hline & CAT & RCAT \\
\hline $\begin{array}{l}\text { reaction temperature } /{ }^{\circ} \mathrm{C} \\
\text { reakcijska temperatura } /{ }^{\circ} \mathrm{C}\end{array}$ & 520 & 520 \\
\hline $\begin{array}{c}\text { catalyst-to-oil mass ratio } \\
\text { maseni omjer katalizator/nafta }\end{array}$ & 6 & 6 \\
\hline WHSV $/ \mathrm{h}^{-1}$ & 19 & 19 \\
\hline $\begin{array}{l}\text { product } \\
\text { proizvod }\end{array}$ & \multicolumn{2}{|c|}{$\begin{array}{c}\text { product yield by mass } / \% \\
\text { iskorištenje proizvoda po masi } / \%\end{array}$} \\
\hline $\begin{array}{l}\text { dry gas } \\
\text { suhi plin }\end{array}$ & 1.75 & 2.01 \\
\hline LPG & 13.39 & 13.71 \\
\hline $\begin{array}{l}\mathrm{C}_{5+} \text { gasoline } \\
\text { benzin } \mathrm{C}_{5+}\end{array}$ & 42.83 & 41.23 \\
\hline LCO & 20.97 & 21.26 \\
\hline $\begin{array}{l}\text { heavy oil } \\
\text { teško ulje }\end{array}$ & 13.68 & 14.20 \\
\hline $\begin{array}{l}\text { coke } \\
\text { koks }\end{array}$ & 7.37 & 7.59 \\
\hline $\begin{array}{l}\text { conversion } \\
\text { konverzija }\end{array}$ & 65.35 & 64.54 \\
\hline $\begin{array}{l}\text { light oil } \\
\text { lako ulje }\end{array}$ & 63.80 & 62.49 \\
\hline $\begin{array}{l}\text { total liquid } \\
\text { ukupno kapljevine }\end{array}$ & 77.19 & 76.20 \\
\hline \multicolumn{3}{|c|}{$\begin{array}{l}\text { product selectivity (yield-to-conversion ratio) } \\
\text { selektivnost (omjer iskorištenja i ukupne konverzije) }\end{array}$} \\
\hline $\begin{array}{l}\text { dry gas } \\
\text { suhi plin }\end{array}$ & 0.028 & 0.031 \\
\hline LPG & 0.21 & 0.21 \\
\hline $\begin{array}{l}\text { gasoline } \\
\text { benzin }\end{array}$ & 0.66 & 0.64 \\
\hline $\begin{array}{l}\text { coke } \\
\text { koks }\end{array}$ & 0.11 & 0.12 \\
\hline
\end{tabular}

Table 5 - PONA analyses and gasoline octane number Tablica 5 - Analiza PONA i oktanski broj benzina

\begin{tabular}{|c|c|c|}
\hline & CAT & RCAT \\
\hline $\begin{array}{l}\text { components } \\
\text { komponente }\end{array}$ & \multicolumn{2}{|c|}{$\begin{array}{l}\text { volume fraction } / \% \\
\text { obujamski udjel } / \%\end{array}$} \\
\hline $\begin{array}{l}\text { normal paraffins } \\
\text { normalni parafini }\end{array}$ & 4.15 & 4.06 \\
\hline $\begin{array}{l}\text { branched-chain paraffins } \\
\text { parafini razgranatog lanca }\end{array}$ & 20.34 & 19.49 \\
\hline $\begin{array}{l}\text { Olefins } \\
\text { Olefini }\end{array}$ & 19.15 & 21.66 \\
\hline $\begin{array}{l}\text { naphthenes } \\
\text { nafteni }\end{array}$ & 12.81 & 14.52 \\
\hline \multirow[t]{2}{*}{$\begin{array}{l}\text { aromatics } \\
\text { aromati }\end{array}$} & 43.55 & 40.27 \\
\hline & \multicolumn{2}{|c|}{$\begin{array}{l}\text { octane number } \\
\text { oktanski broj }\end{array}$} \\
\hline $\begin{array}{l}\text { research octane number } \\
\text { istraživački oktanski broj }\end{array}$ & 93.4 & 92.7 \\
\hline $\begin{array}{l}\text { motor octane number } \\
\text { motorni oktanski broj }\end{array}$ & 82.8 & 82.6 \\
\hline
\end{tabular}


form had a relative crystallinity higher than $55 \%$ with a silica/alumina molar ratio of 5.4. After the modification and steaming stabilization process, an FCC catalyst for maximizing light oil yield was prepared. The results of nitrogen adsorption-desorption isotherm measurements showed that the as-prepared catalyst had more meso- and macropores due to the unique synthesis route. The results of acidity characterization exhibited that the CAT had more acid sites than the commercial one. The catalytic cracking results showed that compared to the commercial catalyst, light oil yields of the CAT had increased by $1.31 \%$, the coke and dry gas yield had decreased by $0.26 \%$ and $0.22 \%$ points, respectively.

\section{ACKNOWLEDGEMENTS}

Financial support was provided by the National Natural Science Foundation of China (No. 21371055), Hunan provincial Natural Science Foundation of China (No. 11Jj2008), Hunan provincial Colleges and Universities Innovation Platform Open Fund Project (No. 15K049).

\section{List of abbreviations and symbols Popis kratica i simbola}

\begin{tabular}{|c|c|}
\hline BET & - Brunauer-Emmett-Teller \\
\hline $\mathrm{BJ} \mathrm{H}$ & - Barrett-Joyner-Halenda \\
\hline CAT & $\begin{array}{l}\text { - catalyst } \\
\text { - katalizator }\end{array}$ \\
\hline $\mathrm{CM}$ & $\begin{array}{l}\text { - calcined microspheres } \\
\text { - kalcinirane mikrosfere }\end{array}$ \\
\hline FAU & $\begin{array}{l}\text { - Faujasite } \\
\text { - Faujasit }\end{array}$ \\
\hline FCC & $\begin{array}{l}\text { - fluid catalytic cracking } \\
\text { - katalitičko krekiranje u fluidiziranom sloju }\end{array}$ \\
\hline FTIR & $\begin{array}{l}\text { - Fourier-transform infrared spectroscopy } \\
\text { - infracrvena spektroskopija s Fourierovom } \\
\text { transformacijom }\end{array}$ \\
\hline LCO & $\begin{array}{l}\text { - light cycle oil } \\
\text { - lako cikličko ulje }\end{array}$ \\
\hline LPG & $\begin{array}{l}\text { - liquefied petroleum gas } \\
\text { - ukapljeni naftni plin }\end{array}$ \\
\hline MAT & $\begin{array}{l}\text { - microactivity test } \\
\text { - test mikroaktivnosti }\end{array}$ \\
\hline PM & $\begin{array}{l}\text { - precursor microspheres } \\
\text { - prekursorske mikrosfere }\end{array}$ \\
\hline PONA & $\begin{array}{l}\text { - paraffins, olefins, naphthenes, aromatics } \\
\text { - parafini, olefini, nafteni, aromati }\end{array}$ \\
\hline RCAT & $\begin{array}{l}\text { - reference catalyst } \\
\text { - referentni katalizator }\end{array}$ \\
\hline SARA & $\begin{array}{l}\text { - saturates, aromatics, resins, and asphaltenes } \\
\text { - zasićeni ugljikovodici, aromatski spojevi, smole i } \\
\text { asfalteni }\end{array}$ \\
\hline SCM & $\begin{array}{l}\text { - synthesized composite material } \\
\text { - sintetizirani kompozitni materijal }\end{array}$ \\
\hline SEM & $\begin{array}{l}\text { - scanning electron microscope } \\
\text { - skenirajuća elektronska mikroskopija }\end{array}$ \\
\hline
\end{tabular}

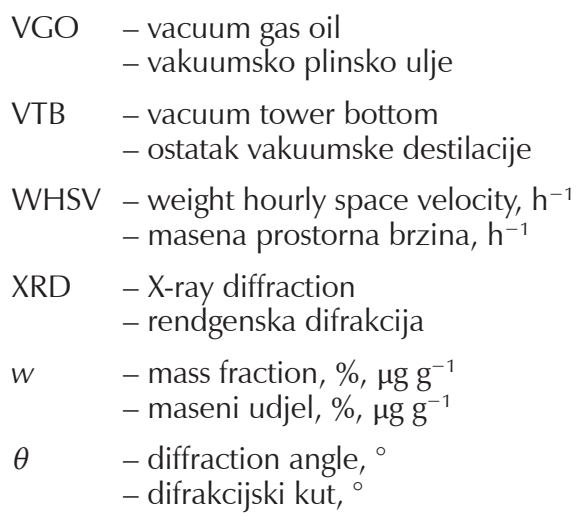

\section{References}

\section{Literatura}

1. M. Milina, S. Mitchell, N.-L. Michels, J. Kenvin, J. PérezRamírez, Interdependence between porosity, acidity, and catalytic performance in hierarchical ZSM-5 zeolites prepared by post-synthetic modification, J. Catal. 308 (2013) 398-407, doi: http://dx.doi.org/10.1016/j.jcat.2013.08.020.

2. K. Xiong, C. X. Lu, Z. F. Wang, X. H. Gao, Kinetic study of catalytic cracking of heavy oil over an in-situ crystallized FCC catalyst, Fuel 142 (2015) 65-72, doi: http://dx.doi. org/10.1016/j.fuel.2014.10.072.

3. Y. C. Qin, X. H. Gao, H. T. Zhang, S. H. Zhang, L. G. Zheng, Q. Li, Z. S. Mo, L. H. Duan, X. T. Zhang, L. J. Song, Measurements and distinguishment of mass transfer processes in fluid catalytic cracking catalyst particles by uptake and frequency response methods, Catal. Today 245 (2015) 147-154, doi: http://dx.doi.org/10.1016/j.cattod.2014.06.007.

4. H. Y. Liu, T. Shen, T. S. Li, P. Yuan, G. Shi, X. J. Bao, Green synthesis of zeolites from a natural aluminosilicate mineral rectorite: Effects of thermal treatment temperature, Appl. Clay Sci. 90 (2014) 53-60, doi: http://dx.doi.org/10.1016/j. clay.2014.01.006.

5. H. H. Liu, H. J. Zhao, X. H. Gao, J. T. Ma, A novel FCC catalyst synthesized via in situ overgrowth of $\mathrm{NaY}$ zeolite on kaolin microspheres for maximizing propylene yield, Catal. Today 125 (2007) 163-168, doi: http://dx.doi.org/10.1016/j.cattod.2007.05.005.

6. Y. D. Wang, B. J. Shen, J. C. Li, B. Feng, X. H. Li, S. Y. Ren, Q. X. Guo, Interaction of coupled titanium and phosphorous on USY to tune hydrodesulfurization of 4,6-DMDBT and FCC LCO over NiWcatalyst, Fuel Process. Technol. 128 (2014) 166-175, doi: http://dx.doi.org/10.1016/j. fuproc.2014.07.019.

7. F. E. Tuler, R. Portela, P. Ávila, E. D. Banús, E. E. Miró, V. G. Milt, Structured catalysts based on sepiolite with tailored porosity to remove diesel soot, Appl. Catal. A 498 (2015) 41-53, doi: http://dx.doi.org/10.1016/j.apcata.2015.03.019.

8. K. Núñez, R. Gallego, J. M. Pastor, J. C. Merino, The structure of sepiolite as support of metallocene co-catalyst during in situ polymerization of polyolefin (nano)composites, Appl. Clay Sci. 101 (2014) 73-81, doi: http://dx.doi.org/10.1016/j. clay.2014.07.020.

9. F. F. Li, Y. Z. Dai, M. Gong, T. P. Yu, X. J. Chen, Synthesis, characterization of magnetic-sepiolite supported with $\mathrm{TiO}_{2}$, and the photocatalytic performance over $\mathrm{Cr}(\mathrm{VI})$ and 2,4-dichlorophenol co-existed wastewater, J. Alloys Compd. 638 (2015) 435-442, doi: http://dx.doi.org/10.1016/j.jallcom.2015.03.070. 
10. B. R. Mitchell, Metal contamination of cracking catalysts 1. Synthetic metals deposition on fresh catalysts, Ind. Eng. Chem. Prod. Res. Dev. 19 (1980) 209-213, doi: http://dx. doi.org/10.1021/i360074a015.

11. M. Önal, H. Yilmaz, Y. Sarikaya, Some physicochemical properties of the white sepiolite known as pipestone from Eskişehir, Turkey, Clays and Clay Miner. 56 (2008) 511-519, doi: http://dx.doi.org/10.1346/CCMN.2008.0560504.

12. N. Hosseinpour, Y. Mortazavi, A. Bazyari, A. A. Khodadadi, Synergetic effects of Y-zeolite and amorphous silica-alumina as main FCC catalyst components on triisopropylbenzene cracking and coke formation, Fuel Process. Technol. 90 (2009) 171-179, doi: http://dx.doi.org/10.1016/j. fuproc.2008.08.013.

13. P. O'Sullivan, L. Forni, B. K. Hodnett, The role of acid site strength in the beckmann rearrangement. Ind. Eng. Chem. Res. 40 (2001) 1471-1475, doi: http://dx.doi.org/10.1021/ ie000673q.

14. S. H. Sun, S. Q. Zheng, Z. F. Wang, Y. H. Zhang, J. T. Ma, Sulphur reduction additive prepared from caustic-modified kaolin, Clay Miner. 40 (2005) 311-316, doi: http://dx.doi. org/10.1180/0009855054030174.

15. H. J. Lee, Y. M. Kim, O. S. Kweon, I. J. Kim, Crystal growing and reaction kinetic of large NaX zeolite crystals, J. Eur. Ceram. Soc. 27 (2007) 581-584, doi: http://dx.doi.org/10.1016/j. jeurceramsoc.2006.04.112.

16. C. Covarrubias, R. García, R. Arriagada, J. Yánez, M. T. Garland, $\mathrm{Cr}$ (III) exchange on zeolites obtained from kaolin and natural mordenite, Microporous Mesoporous Mater. 88 (2006) 220-231, doi: http://dx.doi.org/10.1016/j.micromeso.2005.09.007.

17. L. Patrylak, R. Likhnyovskyi, V. Vypyraylenko, R. Leboda, J. Skubiszewska-Zieba, Adsorption properties of zeolite-containing microspheres and FCC catalysts based on Ukrainian kaolin, Adsorpt. Sci. Technol. 19 (2001) 525-540, doi: http:// dx.doi.org/10.1260/0263617011494376.

18. K. Miyazawa, S. Inagaki, Control of the microporosity within the pore walls of ordered mesoporous silica SBA- 15. Chem. Commun. 21 (2000) 2121-2122, doi: http://dx.doi. org/10.1039/b005128o.

\section{SAŽETAK \\ Novi FCC katalizator temeljen na poroznom kompozitnom materijalu sintetiziran in situ

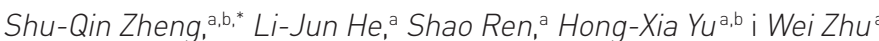

Da bi se prevladala ograničenja difuzije i poboljšao prijenos u mikroporoznim zeolitima, razvijeni su materijali s velikim porama. $U$ ovom su radu sintetizirane kompozitne mikrosfere in situ iz sepiolita, kaolina i pseudoboehmita. Iz kompozitnog materijala dobiven je novi katalizator namijenjen krekiranju u fluidiziranom sloju (FCC), za ostvarivanje najvećeg iskorištenja s obzirom na lako ulje. Katalizator je ispitan rendgenskom difrakcijom, infracrvenom spektroskopijom, elektronskom mikroskopijom, adsorpcijom i desorpcijom dušika te testiran u FCC reaktoru. Katalizator ima više mezopora i makropora te više kiselih aktivnih mjesta od referentnog katalizatora te povećava iskorištenje s obzirom na lako ulje za 1,31 \% uz bolju selektivnost prema benzinu i koksu.

Ključne riječi

Katalizator FCC, hijerarhijska porozna struktura, sinteza in situ, katalitička svojstva

a Department of Chemistry and Chemical Engineering, Hunan Institute of Science and Technology, Yueyang 414 006, Hunan, Kina

${ }^{\mathrm{b}}$ Hunan Province Key Laboratory of Specialty Petrochemicals Catalysis and Separation, Yueyang 414 000, Hunan, Kina
Izvorni znanstveni rad Prispjelo 29. lipnja 2015. Prihvaćeno 28. srpnja 2015. 